University of Nebraska - Lincoln

DigitalCommons@University of Nebraska - Lincoln

Papers in the Earth and Atmospheric Sciences

Earth and Atmospheric Sciences, Department

$1-1907$

\title{
REPORT OF THE GEOLOGICAL EXPEDITION OF HON. CHARLES H. MORRILL. SEASON OF 1906
}

\author{
Erwin Hinckley Barbour \\ University of Nebraska-Lincoln
}

Follow this and additional works at: https://digitalcommons.unl.edu/geosciencefacpub

Part of the Earth Sciences Commons

Barbour, Erwin Hinckley, "REPORT OF THE GEOLOGICAL EXPEDITION OF HON. CHARLES H. MORRILL. SEASON OF 1906" (1907). Papers in the Earth and Atmospheric Sciences. 352.

https://digitalcommons.unl.edu/geosciencefacpub/352

This Article is brought to you for free and open access by the Earth and Atmospheric Sciences, Department of at DigitalCommons@University of Nebraska - Lincoln. It has been accepted for inclusion in Papers in the Earth and Atmospheric Sciences by an authorized administrator of DigitalCommons@University of Nebraska - Lincoln. 
The MorrILL geological expedition of the University of Nebraska for the season of 1906 continued the work of the previous season by developing the bone quarry on University Hill, at Agate, Sioux County, $\mathrm{Ne}$ braska. This quarry is situated on the eastern extremity of Mr. James Cook's ranch, which is an extensive one, and probably the best known in the state. In addition to the uplands it contains some ten square miles along the valley of the Niobrara. The high bluffs adjacent to and beyond this model ranch are fossiliferous, while at Carnegie Hill and University Hill there are literal bone beds. The discovery of these beds was made some twenty years ago by Mr. James Cook. They were first visited by the Morrill geological expedition of 1892, when a considerable number of bones were collected, several of which have 
been figured in the 'University . Studies,' January, 1897, plate 1, Figs. 5, 6, 7.

Pursuant to invitations from Mr. Cook, the Morrill geological expedition of 1905 spent that summer developing the bone quarry on University Hill. During the summers of 1905 and 1906 the members of the exploring party enjoyed all the privileges and hospitalities of this famous ranch. The members of the party for 1906 were: Harold J. Cook, Eck F. Schramm, Edwin Davis and Paul Butler, students in the University of Nebraska. As in former expeditions the writer was in charge.

By the judicious use of dynamite large amounts of overlying rock were removed and a broad surface of the bone-bearing layer exposed. A large number of bones, jaws and skulls were secured, all being for the most part in a fine state of preservation.

The prize specimens of the season were two large slabs cut from the bone-bearing layer and shipped bodily. They are literally packed with bones and jaws, which will be worked out but not removed from their original position. When done they will be placed on exhibition intact, to illustrate fossil bone beds. The bones of Moropus and Diceratherium are so abundant in this quarry that they far outnumber all else. Of the rare Moropus the Morrill collections now have enough material for a complete restoration. There was found to be considerable variation in the size of Moropus bones, some being of elephantine size. Of Diceratherium a great number of bones and jaws, but no good skulls were secured.

In August the writer, accompanied by Mr. Harold Cook, spent ten days exploring and collecting relics in and around the "Spanish Diggings' west of the Rawhide range in Wyoming, where among other things over a thousand stone implements were procured. A few weeks later the writer again visited this spot in company with Dr. M. H. Everett and Edwin Davis at the invitation of Mr. Thomas Black of Willow, Wyo., who not only entertained the expedition in a most hospitable manner but provided teams and conveyance. A wide area was explored and many specimens and implements added to the previous lot. Later a third trip was made to this region by Dr. Everett, who secured additional specimens and data of value. A mild fall, free from the hindrances of rain and snow, has made the continuance of field work possible to the present date. Several days were spent by the writer, accompanied by Dr. George E. Condra, Edwin Davis and Paul Butler, excavating the mound recently discovered by Mr. Robert F. Gilder of Omaha, many human remains of a primitive order being secured. Among miscellaneous acquisitions of the year may be mentioned the skeletons of four modern elephants, camels, bear, etc., secured early in the season by Mr. Henry Eakin.

The Morrill collections will be moved into their new fire-proof quarters the latter part of December, and more than one hundred tons of material now boxed and stored in the basements of various buildings and the steam tunnels on the campus will be placed on exhibition. The benefactions of Hon. Charles H. Morrill make these expeditions possible, and it is planned to greatly increase their extent and scope each year.

The University of Nebraska, ErwiN H. Barbour December 6, 1906 